\title{
IMPLEMENTASI ANGGARAN DESA DALAM MENINGKATKAN PEMBANGUNAN DESA (SUATU PENELITIAN DI GAMPONG LAMDINGIN KOTA BANDA ACEH)
}

\author{
Muhammad Daud \\ Program Studi Ilmu Administrasi Negara Fakultas Ilmu Sosial dan Ilmu Politik \\ Universitas Terbuka-Banda Aceh, E-mail: daud_ut@gmail.com
}

\begin{abstract}
Abstrak: Penelitian yang berjudul "Implementasi Anggaran Desa Dalam Meningkatkan Pembangunan Desa" (Suatu Penelitian di Gampong Lamdingin Kota Banda Aceh) dimaksudkan untuk mengetahui proses implementasi anggaran dalam meningkatkan pembangunan desa di gampong Lamdingin Kota Banda Aceh. Metode yang digunakan dalam penelitian ini adalah kualitatif berbentuk deskriptif, teknik pengumpulan data dilakukan dengan observasi dan wawancara dengan Keuchik Gampong Lamdingin Kota Banda Aceh. Hasil penelitian yang peneliti temukan dilapangan bahwa proses implementasi anggaran desa dalam meningkatkan pembangunan desa mengalokasikan dana Gampong/Desa dengan baik dan transparan, sikap terbuka dengan masyarakat, membangun Gampong dengan cara gotong royong dan bahu membahu dengan masyarakat Gampong, partisipasi masyarakat yang sangat tinggi dalam membangun Gampong, seperti: memberikan uang, memberikan harta yang bermanfaat kepada Gampong demi kepentingan bersama, dan menyumbangkan pikiran kepada Gampong demi meningkatkan pembangunan, pembangunan infrastruktur yang merata dan kinerja aparatur Gampong yang pro rakyat sehingga dapat meningkatkan pembangunan Gampong khususnya di Lamdingin Kota Banda Aceh.
\end{abstract}

\section{Kata Kunci: Implementasi, Dana Desa, Meningkatkan Pembangunan}

\begin{abstract}
The research with the title" village budget implementation in an effort to boost the development of the village" ( The research is implemented in Gampong Lamdingin banda Aceh) with the intention of budget implementation process in order to improve the development of the village toward Gampong Lamdingin Banda Aceh. This research used qualitative descriptive method, by doing an observation and interview with Keuchik Gampong Lamdingin Banda aceh as the data collection techniques interviews. Within this research, the researcher found that the budget execution process as an effort to boost rural development have done well and transparently, with an open attitude toward the public, and develop the village by way of mutual cooperation and word together with the people in the village. The high level of public participation in the effort to build the village, such as giving money, giving the treasure that is beneficial to the village of mutual interest, as well as contribute ideas to the village for the progress of the village. So with uneven infrastucture development and performance of theapparatus Gampong pro people can improve the gampong development, especially in this case Gampong Lamdingin Banda Aceh. "Village Budget Implementation in an Effort to Boost Rural Development" Study Case In Gampong Lamdingin Banda Aceh. The research with the title "Village budget implementation in an effort to boost the development of the Village"( Study Case in Gampong Lamdingin Banda Aceh) with the intention of budget implementation process in order to improve the development of the village toward Gampong Lamdingin Banda Aceh. This research used qualitative descriptive method. By doing an observation and interviews with Keuchik Gampong Lamdingin Banda Aceh as the data collection techniques. Within this research, the researcher found that the budget execution process as an effort to boost rural development have done well and transparently, with an open attitude towards the public, and develop the village by way of mutual cooperation and work together with the people in the village. The high level of public participation in the effort
\end{abstract}


to build the village, such as giving money, giving the treasure that is beneficial to the village of mutual interest, as well as contribute ideas to the village for the progress of the village. So with uneven infrastucture development and performance of the apparatus Gampong pro people can improve the Gampong development, especially in this case Gampong Lamdingin Banda Aceh.

\section{Keywords: Imlementation, the budget of the village, promote development}

Desa adalah suatu wilayah yang memiliki hak otonom untuk mengatur dan meningkatkan pembangunan sendiri dan masyarakat. Seiring dengan diberlakukannya Undang-Undang Nomor 32 Tahun 2004 Pemerintahan menetapkan Peraturan Pemerintah Nomor 72 tahun 2005 tentang desa. Undang-Undang ini pembangunan desa didasarkan pada kinerja ketiga instansi yaitu, Pemerintahan Desa, Badan Pemusyawaratan Desa, dan Lembaga Pemberdayaan Desa.

Tujuan utama Undang-Undang Nomor 32 Tahun 2004 ini adalah untuk membebaskan pemerintah pusat dari beban-beban yang tidak perlu dalam menangani urusan domestik sehingga berkesempatan untuk mempelajari, memahami, merespon berbagai kecenderungan global dan mengambil manfaat darinya (Rosidin, 2010:48). Artinya, dengan adanya otonomi daerah tersebut, maka daerah memiliki kesempatan yang seluasluasnya membangun struktur pemerintah yang sesuai dengan kebutuhan daerah sendiri, serta mampu mengembangkan sistem manajemen yang efektif.

Desa memiliki peran yang sangat penting dalam melaksanakan pemerintahannya, karena desa dapat dikatakan sebagai tolak ukur keberhasilan baik kebijakan, program, dan berbagai perundang-undangan dari pemerintah yang harus dilaksanakan dengan baik oleh pemerintah desa. Selain itu, desa juga mampu melaksanakan program-program nasional, program nasional ini dimulai dari tingkat nasional hingga ke Provinsi.

Melaksanakan tugas pemerintahan desa tentunya didukung dengan kondisi keuangan yang baik pula, bukan hanya itu tetapi dalam membangun meningkatkan pembangunan yang ada di desa, keuangan hal yang diutamakan sesuai denagn yang diharapkan khususnya bagi masyarakat yang ada di desa tersebut. Alokasi Dana Desa (ADD) merupakan bagian keuangan desa yang diperoleh dari dana perimbangan keuangan Pusat dan Daerah yang diterima oleh Kabupaten/Kota untuk dibagikan kepada tiap-tiap desa guna untuk meningkatkan pembangunan di desa dan untuk kesejahteraan masyarakat desa.

Sumber keuangan desa bukan hanya dari pemerintah Provinsi, Kabupaten/Kota melainkan juga dari Anggaran Pendapatan Belanja Desa (APBDes), seperti: Pajak Bumi Bangunan (PBB) masyarakat desa, dari pasar desa, dan sebagainya. APBDes merupakan instrumen yang paling penting yang dapat menentukan terwujudnya tata pemerintahan yang baik di desa. Dimulai dari kesejahteraan masyarakat desa sampai dengan pembangunan yang ada di desa.

Terkait dengan pelaksanaan di desa, banyak sekali permasalahan yang ada di desa yang berkaitan dengan keuangan, baik dari Pemerintah Kabupaten/Kota ataupun dari APBDes. Hal ini 
JURNAL HUMANIORA

juga disebabkan oleh empat faktor, yaitu: Pertama, desa memiliki APBDes yang kecil dan sumber pendapatannya tergantung bantuan yang kecil pula. Kedua, kesejahteraan masayarakat desa rendah. Ketiga, rendahnya dana operasional desa untuk menjalankan pelayanan. Keempat, bahwa banyak program pembangunan masuk desa, tetapi hanya dikelola oleh dinas.

Anggaran sangat penting dalam meningkatkan pembangunan yang ada di desa, dengan adanya pembangunan desa yang maksimal maka dapat menciptakan tata kelola yang baik di desa tersebut. Kaho (2002:40) mengatakan bahwa ada empat hal yang paling penting dalam partisipasi masyarakat terhadap proses pelaksanaan pembangunan, yaitu: Pertama, partisipasi dalam keputusan atau perencanaan. Kedua, partisipasi pelaksanaan. Ketiga, partisipasi dalam memanfaatkan hasil. Keempat, partisipasi dalam mengevaluasi. Selain dari anggaran desa, peran dari masyarakat juga sangat berpengaruh dalam meningkatkan pembangunan di desa.

Lamdingin merupakan salah satu desa/gampong yang terletak di Kota Banda Aceh, dimana pembangunan yang ada di gampong Lamdingin ini tergolong maju apabila dibandingkan dengan gampong-gampong yang lain di Kota Banda Aceh. Anggaran untuk gampong Lamdingin mencapai Rp. 1.4 Miliar untuk tahun 2017, sehingga pembangunan akan cepat terwujud. Selain itu, masyarakat gampong juga mendukung program-program khususnya pembangunan yang ada di gampong Lamdingin tersebut.

Berdasarkan latar belakang diatas, peneliti tertarik untuk melakukan ini dengan mengangkat judul "Implementasi Anggaran Desa Dalam Meningkatkan Pembangunan Desa" (Suatu Penelitian di Gampong Lamdingin Kota Banda Aceh).

Adapun rumusan masalah yang ingin peneliti lakukan adalah "Bagaimanakah proses implementasi anggaran dalam meningkatkan pembangunan desa di gampong Lamdingin Kota Banda Aceh"?

Adapun tujuan dari penelitian ini adalah untuk mengetahui bagaimanakah proses implementasi anggaran dalam meningkatkan pembangunan desa di gampong Lamdingin Kota Banda Aceh.

\section{KAJIAN PUSTAKA}

Edward III dalam Adrianus (2015:7) mengatakan bahwa: Pertama, komunikasi, komunikasi merupakan proses penyampaian informasi dari komunikator kepada komunikasi. Sementara itu, komunikasi kebijakan berarti merupakan proses penyampaian informasi kebijakan dari pembuat kebijakan (policy makers) kepada pelaksana kebijakan (policy implementors) (Widodo, 2011:97). Widodo juga menambahkan bahwa informasi perlu disampaikan kepada pelaku kebijakan dapat memahami apa yang menjadi isi, tujuan, arah, kelompok sasaran (target group) kebijakan, sehingga pelaku kebijakan dapat mempersiapkan hal-hal apa saja yang berhubungan dengan pelaksanaan kebijakan, agar proses implementasi kebijakan bisa berjalan efektif serta sesuai dengan tujuan kebijakan itu sendiri.

Komunikasi dalam implemntasi kebijakan mencakup beberapa dimensi penting yaitu transformasi implemntasi (transmisi), kejelasan 
informasi (clarity) dan konsistensi (consistency). Dimensi transformasi menghendaki agar informasi tidak hanya disampaikan kepada pelaksana kebijakan tetapi juga kepada kelompok sasaran dan pihak yang terkait. Dimensi kejelasan menghendaki agar informasi yang jelas mudah dipahami, selain itu untuk menghindari kesalahan interpretasi dari pelaksana kebijakan, kelompok sasaran maupun pihak yang terkait dalam implemntasi kebijakan. Sedangkan dimensi konsistensi menghendaki agar informasi yang disampaikan harus konsisten sehingga tidak menimbulkan kebingungan pelaksana kebijakan, kelompok sasaran maupun pihak terkait.

Kedua, sumber daya, sumber daya memiliki peranan sangat penting implementasi dalam kebijakan. Sebagimana yang disampaikan oleh Widodo dalam Adrianus (2015:8) bahwa bagaimanapun jelas dan konsistensinya ketentuanketentuan dan aturan-aturan tersebut, jika para pelaksana kebijakan yang bertanggung jawab untuk melaksanakan kebijakan kurang mempunyai sumber-sumber daya untuk melaksanakan kebijakan secara efektif maka implementasi kebijakan tersebut tidak akan efektif. Sumber daya ini mencakup sebagai berikut: (1) sumber daya manusia (staff), impelementasi kebijakan tidak akan berhasil tanpa adanya dukungan dari sumber daya manusia yang cukup kualitas dan kuantitasnya. (2) anggaran (Budgetary), sangat berkaitan dengan kecukupan modal atau investasi atas suatu program atau kebijakan untuk menjamin terlaksananya kebijakan, sebab tanpa adanya dukungan anggaran yang memadai, kebijakan tidak akan berjalan efektif dan mencapai sasaran dan tujuannya. (3) fasilitas (facility), merupakan salah satu faktor yang berpengaruh dalam kebijakan. (4) informasi dan kewenangan (information and authority) informasi sangat penting sekali dalam pelaksanaan kebijakan, terutama informasi yang relevan sangat dan cukup terkait bagaimana mengimplementasikan suatu kebijakan. Wewenang juga sama pentingnya dengan informasi untuk meyakinkan dan menjamin bahwa kebijakan yang dilaksanakan sesuai dengan yang dikehendaki.

Ketiga, disposisi (disposition), kecenderungan perilaku atau karakteristik dari pelaksana kebijakan berperan penting untuk mewujudkan implementasi kebijakan yang sesuai dengan tujuan atau sasaran. Karakter penting yang harus dimiliki oleh pelaksana kebijakan misalnya kejujuran dan komitmen yang tinggi. Kejujuran mengarahkan implementor untuk tetap berada dalam asa program yang telah digariskan, sedangkan komitmen yang tinggi dari pelaksana kebijakan akan membuat mereka selalu antusias dalam melaksanakan tugas, wewenang, fungsi, dan tanggung jawab sesuai dengan peraturan yang telah ditetapkan.

Terakhir, Keempat, struktur birokrasi (bureucratic structure), struktur birokrasi sangat penting juga dalam implementasi kebijakan, pasalnya struktur organisasi ini melingkupi dua hal yaitu mekanisme dan strukur dan birokrasi. Aspek mekanisme dalam implementasi kebijakan biasanya sudah dibuat standart operation procedur (SOP). SOP menjadi pedoman bagi setiap impelementor dalam bertidak agar dalam pelaksanaan kebijakan tidak melenceng dari tujuan dan sasaran kebijakan. Aspek struktur birokraasi yang terlalu panjang dan terfragmentasi akan 
cenderung melemahkan pengawasan dan menyebabkan prosedur birokrasi yang rumit dan kompleks yang selanjutnya akan menyebabkan aktifitas organisasi menjadi fleksibel.

Hariyono (2010:21) mengatakan bahwa pembangunan adalah suatu proses perubahan yang direncanakan untuk mencapai tujuan yang lebih baik bagi masyarakat, dan dilakukan dengan norma-norma atau nilai-nilai tertentu. Pembangunan sama halnya seperti merubah hal yang buruk sehingga menjadi lebih baik apabila dipandang. Dalam membangun desa perlu adanya kerjasama yang baik antar masyarakat, gotong royong adalah cara yang paling ampuh dalam melakukan perubahan desa.

Menurut Ndraha dalam Latif (2014:97-98) bahwa ada beberapa bentuk partisipasi, sebagai berikut: Pertama, partisipasi dalam/melalui kontak dengan pihak lain sebagai salah satu titik awal perubahan sosial. Kedua, partisipasi dalam memperhatikan/menyerap dan memberi tanggapan terhadap informasi, baik dalam arti menerima (mentaati, memenuhi, melaksanakan), meniagakan, menerima dengan syarat, maupun dalam arti menolaknya. Ketiga, partisipasi dalam perencanaan pembangunan, termasuk pengambilan keputusan. Perasaan terlibat dalam perencanaan perlu ditumbuhkan sedini mungkin di dalam masyarakat. Keempat, partisipasi dalam pelaksanaan opearasional pembangunan. Kelima, partisipasi dalam menerima, memelihara dan mengembangkan hasil pembangunan. Keenam, partisipasi dalam menilai pembangunan, yaitu keterlibatan masyarakat dalam menilai sejauhmana pelaksana pembangunan sesuai dengan rencana dan sejauhmana hasilnya dapat memenuhi kebutuhan masyarakat.

Menurut Uphof dalam Fracisco (2015:5) bahwa dalam kaitannya dengan bentuk-bentuk partisipasi, terdapat empat jenis partisipasi yaitu partisipasi dalam pengambilan keputusan, pelaksanaan, pemanfaatan hasil serta penilaian pembangunan desa. Selanjutnya, Kaho (2002:40) juga mengatakan bahwa dalam partisipasi masyarakat proses pelaksanaan pembangunan antara lain: partisipasi dalam pengambilan keputusan, partisipasi dalam pelaksanaan, partisipasi dalam memanfaatkan hasil, dan partisipasi dalam mengevaluasi.

Sumaryadi (2010:46) mengatakan bahwa partisipasi berarti peran serta seseorang atau kelompok masyarakat dalam proses pembangunan baik dalam bentuk pernyataan maupun dalam bentuk kegiatan dengan memberi masukan pikiran, tenaga, waktu, keahlian, modal dan atau materi, serta ikut memanfaatkan dan menikmati hasil-hasil pembangunan.

Pembangunan infrastruktur yang merata ini penting sekali dilakukan. Sebagaimana yang dikatakan oleh Effendi dalam Rosalina (2013:5) bahwa pentingnya pembangunan infrastruktur yang memadai yang berupa ketersediaan fasilitas pelayanan publik, baik sarana pendidikan, sarana kesehatan, rumah ibadah, listrik, jalan, jembatan, transportasi, air bersih, drainase, teknologi dan komunikasi bertujuan agar masyarakat dapat bergerak lebih dinamis dan mempermudaj kegiatan ekonomi, serta agar para investor mau menanamkan modal menjadi lebih besar dan berpengaruh pada harga produk yang dihasilkan dan tentunya akan lebih mahal dibandingkan dengan yang lain, sehingga produk yang dihasilkan 
tidak kompetitif.

Sedangkan Stone dalam Rosalina (2013:5) mengemukakan pendapat yang berbeda bahwa infrastruktur didefinisikan sebagai fasilitas-fasilitas fisik yang dikembangkan atau dibutuhkan oleh agen-agen publik untuk fungsi-fungsi pemerintahan dalam penyediaan air, tenaga listrik, pembangunan limbah, transportasi, dan pelayananpelayanan similar untuk memfasilitas tujuan-tujuan ekonomi.

Menurut Moeheriono dalam Irwantoto (2014:9) ada tiga indikator yang diapat digunakan untuk mengukur kinerja: (1) Responsivitas, yaitu menggambarkan kemampuan organisasi publik dalam menjalankan misi dan tujuannya adalah untuk memenuhi kebutuhan masyarakat; (2) Responsibilitas, yaitu pelaksanaan kegiatan organisasi publik dilakukan sesuai dengan prinsipprinsip adminsitrasi yang benar atau sesuai dengan kebijakan secara eksplisit; (3) Akuntabilitas, yaitu menunjuk pada seberapa besar kebijakan dan kegiatan organisasi publik yang diharapkan dari masyarakat, bisa berupa penilaian dari wakil rakyat, pejabat dan masyarakat.

Gibson dalam Irwantoto (2014:9-10) mengatakan bahwa faktor yang berpengaruh terhadap kinerja seseorang yaitu: Pertama, faktor individu, yaitu kemampuan, keterampilan, latar belakang keluarga, pengalaman tingkat sosial; Kedua, faktor psikologis, persepsi, peran, sikap, kepribadian, motivasi, dan kepuasan kerja; Ketiga, faktor organisasi, struktur organisasi, desain pekerjaan, kepemimpinan dan sistem penghargaan (reward system).

\section{METODOLOGI PENELITIAN}

Metode yang peneliti gunakan dalam melakukan penelitian ini adalah kualitatif berbentuk deskriptif, teknik pengumpulan data dilakukan dengan observasi dan wawancara dengan Keuchik Gampong Lamdingin Kota Banda Aceh.

\section{HASIL DAN PEMBAHASAN}

\section{Implementasi Anggaran Alokasi Dana Desa dengan Baik}

Pelaksanaan anggaran Alokasi Dana Desa di Gampong Lamdingin Kota Banda Aceh dilakukan dengan baik oleh aparatur yang ada di Gampong Lamdingin, sebagaimana yang diungkapkan oleh Anas Bidin Nyak Syech (Keuchik Gampong Lamdingin) bahwa komunikasi dengan perangkat Gampong serta masyarakat yang ada di Gampong Lamdingin dengan tujuan jangan terjadinya masalah. Komunikasi ini sangat penting dalam membangun membangun Gampong.

Selanjutnya, Keuchik Gampong Lamdingin juga mengatakan bahwa selain komunikasi, implementasi ini sifatnya juga transparan kepada masyarakat yang ada di Gampong, tidak perlu ditutupi karena anggaran ini semuanya sumber dari negara. Jadi apapun bentuknya, akan kami sampaikan kepada masyarakat agar tidak timbul fitnah, memang selama ini anggaran yang diberikan Pemerintah Kota sejak menjadi Keuchik selalu meningkat setiap tahunnya dan anggaran tersebut lumayan besar, dari Rp. 1.005.000.000 menjadi Rp. 1.400.000.000. (Wawancara pada tanggal 23 Maret 2017) 


\section{Membangun Gampong dengan Gotong Royong}

Ungkapan yang dilontarkan oleh Keuchik Gampong Lamdingin (23 Maret 2017) bahwa gotong royong adalah hal yang paling efektif dalam meningkatkan pembangunan desa, karena masyarakat Gampong turun kelapangan beramairamai, pekerjaan yang beratpun menjadi ringan apabila dikerjakan secara kebersamaan. Adisasmita (2004:4) mengatakan bahwa adalah seluruh kegiatan pembangunan yang berlangsung di desa dan meliputi seluruh aspek kehidupan masyarakat, serta dilaksanakan secara terpadu dengan mengembangkan swadaya gotong royong.

\section{Partisipasi Masyarakat yang Tinggi}

Partisipasi masyarakat Gampong Lamdingin ini sangat besar dalam melakukan pembangunan khususnya pembangunan desa. Ada tiga hal pokok yang dijumpai dalam partisipasi masyarakat yaitu: (1) partisipasi merupakan keterlibatan mental emosional; (2) partisipasi menghendaki adanya kontribusi terhadap kepentingan atau tujuan kelompok; dan (3) partisipasi merupakan tanggungjawab kelompok.

Di Gampong Lamdingin masyarakatnya sangat aktif dalam melaksanakan kegiatankegiatan Gampong, dimulai dari kegiatan yang kecil sampai hal yang besarpun mereka selalu berpartisipasi. Artinya, masyarakat Gampong Lamdingin ingin meningkatkan pembangunan yang ada di Lamdingin.

Dalam kebiasaannya, kebijakan tidak akan sukses apabila pelaksanaan tidak dikaitkan dengan tujuan yang telah ditetapkan. Dalam pelaksanaan pembangunan di Kota Banda Aceh khususnya
Gampong Lamdingin, masyarakat juga diajak untuk melakukan partisipasi tersebut dengan cara menyumbangkan tenaga atau harta terhadap pembangunan yang sifatnya fisik.

Cepatnya proses pembangunan Gampong Lamdingin tentu harus memiliki partisipasi masyarakat yang tinggi. Partisipasi aktif memberikan bantuan dari masyarakat juga diharapkan seperti memberikan tenaga, uang, dan harta benda lainnya demi terwujudnya pembangunan desa yang lebih maksimal dan sangat mutlak diperlukan dalam meningkatkan pembangunan desa. Partisipasi dalam pengambilan keputusan, yaitu dalam pengambilan keputusan merupakan peran aktif masyarakat dalam menentukan kebijakan apa yang akan diputuskan yang sesuai dengan keinginan masyarakat yang bersangkutan. Partisipasi dalam pelaksanaan, yaitu keterlibatan masyarakat secara langsung dalam bentuk materi, umumnya bersifat pada wujud yang terlihat jelas seperti partisipasi dalam bentuk modal maupun sumbangan uang secara sukarela, sumbangan pikiran dari masyarakat itu sendiri.

Partisipasi dalam memanfaatkan hasil, yaitu partisipasi masyarakat dalam menggunakan dan memanfaatkan hasil pembangunan yang telah dilaksanakan secara optimal demi kesejahteraan masyarakat yang ada di Gampong Lamdingin. Selain itu berperan dalam merawat, memelihara, dan menjaga hasil pembangunan tersebut agar hasil pembangunan yang telah dilaksanakan dapat digunakan secara continue dan berlangsung lama. Partisipasi dalam mengevaluasi, ini lebih pada penilaian dari hasil penggunaan dan pemanfaatan pembangunan sebagai suatu pembelajaran dan bahan pertimbangan kedepannya. 


\section{Pembangunan Infrastruktur yang Merata}

Pembangunan-pembangunan jalan Gampong, fasilitas umum lainnya seperti tempat bermain anak-anak, tempat olahraga, dan sebagainya di Gampong Lamdingin dibangun secara merata, adil, dan keberlanjutan. Artinya, apabila tidak selesai tahun ini dikarenakan oleh kendala maka akan dilanjutkan untuk tahun selanjutnya sesuai dengan anggaran. Pembangunan infrastruktur ini harus merata keseluruh mukim yang ada di Lamdingin, apabila tidak merata tentunya akan berakibat negatif juga bagi Gampong Lamdingin, misalnya kecemburuan sosial akibat ketidakadilan pimpinan desa.

Pembangunan infrastuktur yang ada di Gampong Lamdingin seluruh kondisinya baik, tidak ada yang cacat, seluruh infrastruktur ini dapat digunakan dan dinikmati oleh seluruh lapisan masyarakat. Aparatur Gampong yang paling diutamakan adalah fasilitas-fasilitas umum yang harus memadai dan lengkap, agar masyarakatpun buisa menikmati uang mereka bagi yang telah membayar pajak (Wawancara, 23 Maret 2017).

\section{Kinerja Pro Rakyat}

Jawaban ini yang peneliti temukan ketika melakukan wawancara dengan Keuchik Gampong Lamdingin, bahwa aparatur Gampong harus pro rakyat dan mendukung seluruh kegiatan-kegiatan yang baik. Kinerja yang baik merupakan awal dari sebuah kesuksesan dalam mengimplementasikan seluruh kebijakan yang ada di Gampong Lamdingin. Selama ini kinerja yang dilakukan oleh pemerintah Gampong efektif dan efisien, tanpa adanya permasalahan dalam melaksanakan tugas. Artinya kiinerja Keuchik dan aparaturnya dinilai sangat baik dan melayani masyarakat. Sebagaimana yang diungkapkan oleh Amins Dalam Irwantoto (2014:9) bahwa kinerja dinyatakan baik dan sukses jika tujuan yang diinginkan dapat tercapai dengan baik. Selain itu, juga diungkapkan oleh Sudarto dalam Irwantoto (2014:9) bahwa kinerja organisasi yaitu hasil kerja kongkrit yang dapat diukur dari organisasi dan dapat dipengaruhi oleh kinerja sebagai alat ukur, sehingga ukuran kinerja tersebut dapat bersifat kuantitatif atau kualitatif dan tidak selalu mencerminkan potensi orang.

Keberhasilan kinerja yang dilakukan oleh aparatur Gampong Lamdingin adalah kemampuan yang dimiliki oleh setiap aparatur Gampong, memiliki rasa sosial yang tinggi sehingga mampu merangkul masyarakat yang ada di Gampong Lamdingin tersebut. Dalam menciptakan suasana harmonis antara aparatur Gampong dengan masyarakat Gampong, pihak aparatur Gampong selalu mendengarkan keluhan-keluhan masyarakat dari mulut ke mulut.

\section{KESIMPULAN}

Keuchik beserta aparatur Gampong lainnya melakukan implementasi anggaran desa dalam meningkatkan pembangunan Gampong khususnya di Gampong Lamdingin Kota Banda Aceh. Hasil penelitian yang peneliti temukan di lapangan dalam meningkatkan pembangunan Desa/Gampong adalah implementasi anggaran Gampong dikelola dengan baik, dan secara transparan, membangun Gampong dengan gotong royong saling membantu antara satu dengan yang lainnya, partisipasi masyarakat yang sangat tinggi dalam meningkatkan pembangunan Gampong, 
memberikan uang, menyumbangkan pikiran dan sebagainya dalam pembangunan Gampong.

Pembangunan infrastruktur yang merata tanpa adanya diskriminasi antara masyarakat yang satu dengan yang lainnya, mulai dari hal yang terkecil hingga hal yang besar dengan menggunakan anggaran desa secara berkelanjutan berdasarkan dengan anggaran yang ada. Terakhir adalah kinerja aparatur Gampong yang pro terhadap rakyat, selalu mendukung dan mensupport.

\section{DAFTAR PUSTAKA}

Adisasmita, Raharjo. (2006). Membangun Desa Partisipatif. Yogyakarta: Graha Ilmu.

Adrianus, Devaczy, P. John. (2015). Implementasi Kebijakan Anggaran Alokasi Dana Desa Di Desa Sidahari Kecamatan Jelai Hulu Kabupaten Ketapang. Jurnal S-1 Ilmu Pemerintahan, 4 (3).

Francisco, Stepanus. (2015). Partisipasi Masyarakat Dalam Pembangunan Desa Di Desa Marunsu Kecamatan Samalantan Kabupaten Bengkayang. Jurnal S-1 Ilmu Pemerintahan, 4 (3).

Hariyono, Paulus. (2010). Perencanaan Pembangunan Kota dan Perubahan Paradigma. Yogyakarta: Pustaka Belajar.

Irwantoto, Adrianus. (2014). Kinerja Organisasi Pemerintahan Desa Dalam Pembangunan Di Desa Banua Ujung Kecamatan Embaloh Hulu Kabupaten Kapuas Hulu. Jurnal S-1 Ilmu
Pemerintahan, 3 (4).

Kaho, J.R. (2002). Prospek Otonomi Daerah di Negara Kesatuan Republik Indonesia. Jakarta: Rajawali Press.

Rosalina, Maya. (2013). Kinerja Pemerintah Desa Dalam Pembangunan Infrastruktur Di Desa Kuala Lapang dan Desa Taras Kecamatan Malinau Barat Kabupaten Malinau. Ejurnal Pemerintahan Integratif, 1 (1): 106-120.

Rosidin, Utang. (2010). Otonomi Daerah dan Desentralisasi dilengkapi UndangUndang Nomor 32 Tahun 2004 dengan Perubahan-Perubahannya. Bandung: Pustaka Setia.

Widodo, Joko. (2008). Analisis Kebijakan Publik. Konsep dan Analisis Proses Kebijakan Publik. Malang: Bayu Media Publishing. 